\title{
Caveolin-1 is involved in encephalomyocarditis virus replication in BHK-21 cells
}

Qiongyi Li ${ }^{1,2+}$, Yang Liu' ${ }^{1,2+}$, Shujuan Xu ${ }^{1,2}$, Kexue Zhao ${ }^{1,2}$, Ying Ling ${ }^{2}$, Rongxiu Liu ${ }^{2}$, Amjad Ali $^{1}$ and Jialin Bai ${ }^{12^{*}}$ (D)

\begin{abstract}
Background: Encephalomyocarditis virus, member of Cardiovirus genus within Picornaviridae family, is an important pathogen that infects different domestic and wild animals. However, the molecular mechanism of its entry remains unclear. In this study, we investigated the mechanism of EMCV infectivity in relation to endocytic pathway using BHK21 cells.

Methods: The function of numerous cellular key factors implicated in the various endocytic mechanisms were systematically explored using chemical inhibitors. Furthermore, RNA interference (RNAi) as well as the overexpression of dominant protein combined to virus infectivity assays, and confocal microscopy was used to examine EMCV infection in details.

Results: The results indicated that the EMCV entry into BHK-21 cells depends on caveolin, dynamin, and actin but not clathrin nor macropinocytosis pathways. The effects of overexpression and knockdown of caveolin-1, one components of the caveolae, was examined on EMCV infection. The results showed that EMCV infection was positive correlation with caveolin-1 expression. Confocal microscopy analysis and internalization assay showed that caveolin-1 is required at the early stage of EMCV infection.
\end{abstract}

Conclusions: Caveolin-1, dynamin, and actin-dependent endocytosis pathways are necessary for EMCV infection in vitro.

Keywords: Endocytosis, Encephalomyocarditis virus, BHK-21, Caveolin-1, Clathrin, Macropinocytosis, Dynamin, Actin

\section{Background}

Encephalomyocarditis virus (EMCV) is a single-stranded, positive sense RNA virus of the Cardiovirus genus within Picornaviridae family that causes a wide range of diseases in mammalian species [1, 2]. After its first isolation from a captive male gibbon [3], the virus has been

\footnotetext{
*Correspondence: jlbai@xbmu.edu.cn

${ }^{\dagger}$ Qiongyi Li and Yang Liu contributed equally and should be considered asfirst authors

${ }^{1}$ Biomedical Research Center, Key Laboratory of Biotechnology and Bioengineering of State Ethnic Affairs Commission, Northwest Minzu University, Lanzhou, China

Full list of author information is available at the end of the article
}

recovered from various animal species throughout the world [4-7]. EMCV is often used as a model to study antiviral immune responses, virus-induced myocarditis and insulin dependent diabetes mellitus $[8,9]$. However, the mechanisms involved in the internalization and entry of the cardioviruses are still not well elucidated $[2,8]$.

Many viruses can trigger internalization by activating endocytic process such as macropinocytosis, clathrin-mediated endocytosis (CME) and caveolar/lipid raft-dependent, or clathrin- and caveolae-independent endocytic pathways are utilized by different viruses for their entry and replication in permissive cell [10-12]. Members of Picornaviridae family use different endocytic mechanisms for infection to occur. Pietia "inen et al. original author(s) and the source, provide a link to the Creative Commons licence, and indicate if changes were made. The images or other third party material in this article are included in the article's Creative Commons licence, unless indicated otherwise in a credit line to the material. If material is not included in the article's Creative Commons licence and your intended use is not permitted by statutory regulation or exceeds the permitted use, you will need to obtain permission directly from the copyright holder. To view a copy of this licence, visit http://creativecommons.org/licenses/by/4.0/. The Creative Commons Public Domain Dedication waiver (http://creativeco mmons.org/publicdomain/zero/1.0/) applies to the data made available in this article, unless otherwise stated in a credit line to the data. 
in their study indicated that EV1 entry to CV-1 cells is dynamin-dependent [13]. Poliovirus infects different host cells using different endocytic pathways, for example, its entery into Hela cells is clathrin- and caveolin-independent while infects brain microvascular endothelial cells, it utilizes caveolin- and dynamin-dependent routes [14-16]. CBV3 enters into HeLa cells using clathrinmediated endocytosis pathway [17] and coxsackie virus A9 entry into A549 cells is mediated by dynamin, $\beta 2$-microglobulin, and Arf6 [12] while FMDV internalization is by clathrin-dependent pathway [18-20]. However, as one member of this family, little is known about the entry mechanism of EMCV.

Based on the above mentioned studies and being a member of the Picornaviridae family, we hypothesized that EMCV may also use the endocytic mechanisms for causing infection. Therefore, we designed this study to investigate $\mathrm{EMCV}$ infection with relation to endocytic pathway using BHK-21 cells. At first, we confirmed that the EMCV replication was related to endocytosis. Subsequently, we demonstrated that neither clathrin nor macropinocytosis pathway was involved in virus infection. We have shown that EMCV replication into the BHK-21 cells via caveolin-mediated and dynamin, actindependent pathway.

\section{Methods}

\section{Cells, viruses, and antibodies}

BHK-21 cells were provided by the Gansu Tech Innovation Center of Animal Cell (Northwest Minzu University, Lanzhou, China) and were maintained in DMEM (Minhai Bio-engineering, Lanzhou, China) supplemented with $10 \%$ FBS (Minhai Bio-engineering) in a $5 \% \mathrm{CO}_{2}$ incubator at $37^{\circ} \mathrm{C}$.

The EMCV strain used in the current study was the BHK-21 cells adapted EMCV (GenBank: X74312) and its titer was $10^{6.0} \mathrm{TCID}_{50} \mathrm{ml}^{-1}$. The plaque-forming unit (PFU) was calculated as previously described [21].

Mouse monoclonal antibody (mAb) against Caveolin-1 and rabbit polyclonal antibody (pAb) anti-Caveolin-1 were bought from Beyotime (Beyotime Biotechnology, Shanghai, China) and MAb against glyceraldehyde3-phosphate dehydrogenase (GAPDH) was purchased from Abcam (Abcam, Cambridge, UK). MAb against EMCV-VP1 was kindly donated by Dr. Juan Bai (College of Veterinary Medicine, Nanjing Agricultural University, China). Anti-GFP mAb were purchased from TransGen (TransGen Biotech, Beijing, China).The HRP-labeled secondary antibody, Alexa fluor-488-conjugated anti-mouse

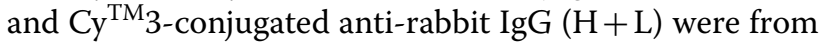
Jackson ImmunoResearch Laboratories (Jackson ImmunoResearch Laboratories, PA, USA).

\begin{tabular}{lll}
$\begin{array}{l}\text { Table } \mathbf{1} \text { The primer sequences used for } \\
\text { overexpresses vector }\end{array}$ & Size (bp) \\
\hline Gene & Primer sequence $\left(5^{\prime}-3^{\prime}\right)$ & 537 \\
\hline Caveolin-1 & F:GCTCTAGAATGTCTGGGGGCAAATACGTGGACTC & 537 \\
& R:CGGGATCCTCATATCTCTTTCTGCGTGCTGATGC &
\end{tabular}

Underlined sequences show restriction enzyme sites (Xbal and BamH I) and start codon

Table 2 The sequence of the caveolin-1 siRNA

\begin{tabular}{ll}
\hline Name of siRNA & Sequence $\left(5^{\prime}-3^{\prime}\right)$ \\
\hline Mus-Cav1-siRNA1 & GCAACATCTACAAGCCCAA \\
Mus-Cav1-siRNA2 & CCACCTTCACTGTGACAAA \\
Mus-Cav1-siRNA3 & CATCAAGAGCTTCCTGATT \\
\hline
\end{tabular}

\section{qRT-PCR}

Total RNA was isolated, followed by qRT-PCR as previously described [22], using primers EMCV-3D qF: GTC ATACTATCGTCCAGGGACTCTAT and qR: CATCTG TACTCCACACTCTCGAATG. GAPDH was used as the internal reference and quantified using specific primers; qF: AAGGCCATCACCATCTTCCA and qR: GCCAGT AGACTCCACAACATAC.

\section{Gene overexpression and RNA interference}

To evaluate the effect of Caveolin-1 in the infection as well as invasion of EMCV into BHK-21 cells, the replication-defective lentivirus system provided by Dr. Enqi $\mathrm{Du}$ (Northwest A\&F University, China), was used to construct a recombinant plasmid to overexpress caveolin-1. Total RNA was extracted from BHK-21 cells and reverse transcribed into cDNA. The caveolin-1 gene was amplified by PCR based on the murine caveolin-1 sequence (GenBank accession No. U07645.1). The amplified PCR product was digested by restriction endonuclease $\mathrm{XbaI}$ and BamH I (NEB, MA, USA) and inserted into pTRIPCMV-IRES-Puro to construct recombinant plasmid, pTRIP-CAV1, using specific primers (Table 1). As a control, a EGFP recombinant plasmid, pTRIP-EGFP, was also constructed. Lentivirus was produced with recombinant lentivirus vector pTRIP-CAV1 and pTRIP-EGFP as described [23] and the transfected cells were named as BHK-CAV1 and BHK-EGFP, respectively.

Moreover, three individual small interfering RNAs (siRNA) against caveolin-1 (Rebobio, Guangdong, China) were designed (Table 2) and were employed to transfect the cells using Invitrogen Lipofectamine 2000 (ThermoFisher, MA, USA) system according to manufacturer's instructions. The silencing efficiencies were measured 
by qRT-PCR and Western Blotting (WB) analysis. After culturing for 2 days, the cells were infected with EMCV and at $9 \mathrm{~h}$ post-infection (hpi), WB and virus infectivity assays were performed.

\section{Chemical inhibitors and cell viability determination}

DMEM supplemented with 10\% FBS and one of the following chemical inhibitors: Nystatin, pitstop, dynasore, mitmab, cytochalasin $\mathrm{D}$, jasplakinolide, chlorpromazine and 1, 1'-Dithiobis-2-naphthalenol (IPA-3) were purchased from Abcam. Methyl- $\beta$-cyclodextrin $(\mathrm{M} \beta C D)$ and $\mathrm{NH}_{4} \mathrm{Cl}$ were purchased from Sigma (Sigma, MO, USA) and bafilomycin A1, EIPA and wortmannin from Solarbio (Solarbio, Beijing, China). Concentration and effects of the inhibitors applied in this study were described in Table 3. Respective cells were treated with inhibitors for one hour before EMCV infection. After RNA interference and chemical inhibitors treatment, cells viability was conducted by the CellTiter $96^{\circledR}$ Aqueous Non-Radioactive Cell Proliferation Assay kit (Promega, WI, USA) according to the manufacturer's instructions. The obtained raw values were converted to percentages in relation to untreated samples and corrected by background absorbance.

\section{Virus infectivity assays, post-entry inhibitory effects and detection of virus internalization}

For virus infectivity assays, cells were incubated with EMCV at 0.1 multiplicity of infection (MOI) for $1 \mathrm{~h}$ at $37{ }^{\circ} \mathrm{C}$ in serum-free medium and then washed three times with pre-warmed phosphate-buffered saline (PBS) and maintained in DMEM with 3\% FBS. At the given time points post infection, the virus replication assay was examined by virus yield titration [24], qRT-PCR and western blotting.
For post-entry inhibitory effects determination, cells were first incubated with EMCV at $0.1 \mathrm{MOI}$. Then after two hoursrs, cells were washed with PBS and culture medium containing chemical inhibitors was added to the cells accordingly. At $9 \mathrm{~h}$ post infection, cells were harvested for further analysis [25].

EMCV internalizing ability into BHK-21, BHK-Cav1 and BHK-EGFP cells was determined by measuring the quantity of infectious viruses in these cells according to previous report [26].

\section{IFA and confocal microscopy}

Cells were fixed using ice cold $75 \%$ ethanol at $4{ }^{\circ} \mathrm{C}$ for $30 \mathrm{~min}$. For co-localization studies, cells were permeabilized with $0.1 \%$ Triton X-100 when needed. After washing cells on slides with PBS, the suitable primary antibody was added and incubated at $37^{\circ} \mathrm{C} .1 \mathrm{~h}$ later, the slides were washed again and $150 \mu$ l secondary antibody was added and incubated for $1 \mathrm{~h}$. Finally, the samples were counterstained with 4, 6-diamidino-2-phenylindole (DAPI) for $5 \mathrm{~min}$ at room temperature and were analyzed under Confocal microscope ZEISS LSM 900 (Zeiss, Oberkochen, Germany).

\section{Western blotting}

Samples were lysed in NP-40 lysis buffer (Beyotime, Shanghai, China) and concentration was measured using the Pierce BCA Protein Assay Kit (Thermo Fisher Scientific, A, USA). Samples were heated at $95^{\circ} \mathrm{C} 5 \mathrm{~min}$ and run on $10 \%$ SDS-PAGE gel and were transferred to PVDF membrane (Millipore, MA, USA). After treatment with $5 \%$ milk for $1 \mathrm{~h}$, the membrane was incubated overnight with the primary antibody at $4{ }^{\circ} \mathrm{C}$ and then treated with HRP-conjugated secondary antibody for $2 \mathrm{~h}$ at room temperature. The specific bands of the membrane were

Table 3 Chemical inhibitors used in this study

\begin{tabular}{lll}
\hline Chemical inhibitor & Effect & Concentration \\
\hline $\mathrm{NH} 4 \mathrm{Cl}$ & Inhibits pH-dependent activation of the fusion protein & $10 \mathrm{mM} / 20 \mathrm{mM}$ \\
Bafilomycin A1 & Vacuolar-type ATPase inhibitor & $10 \mathrm{nM} / 20 \mathrm{nM}$ \\
Chlorpromazine & Inhibits clathrin-dependent endocytosis & $5 \mu \mathrm{M} / 10 \mu \mathrm{M}$ \\
Pitstop-2 & Cell-permeable clathrin inhibitor & $5 \mu \mathrm{M} / 10 \mu \mathrm{M}$ \\
Nystatin & Disrupts caveolae & $12.5 \mu \mathrm{g} / 25 \mu \mathrm{g}$ \\
M $\beta C D$ & Extracts cholesterol from lipid membranes & $2.5 \mathrm{mM} / 5 \mathrm{mM}$ \\
Dynasore & Inhibits GTPase activity & $20 \mu \mathrm{M} / 40 \mu \mathrm{M}$ \\
Mitmab & Blocks the lipid binding & $5 \mu \mathrm{M} / 10 \mu \mathrm{M}$ \\
Cytochalasin D & Disrupts actin polymerization & $5 \mu \mathrm{M} / 10 \mu \mathrm{M}$ \\
Jasplakinolide & Stabilizes actin microfilaments & $5 \mu \mathrm{M} / 10 \mu \mathrm{M}$ \\
EIPA & $\mathrm{NA}+/ \mathrm{H}^{+}$exchanger inhibitor & $10 \mu \mathrm{M} / 20 \mu \mathrm{M}$ \\
IPA-3 & the Pak-1 inhibitor & $7.5 \mu \mathrm{M} / 15 \mu \mathrm{M}$ \\
Wortmannin & the Pl3K inhibitor & $5 \mu \mathrm{M} / 10 \mu \mathrm{M}$ \\
\hline
\end{tabular}


analyzed using chemiluminescence (Cowin Bioscience, Beijing, China) and detected using a Electrophoresis gel imaging split system (Gel imaging system, GE Healthcare Bio-Sciences AB). Protein ladders (10 kDa-180 kDa) used in this study was from YEASEN (Yeasen Biotech, Shanghai, China).

\section{Statistical analyses}

Results are from three independent experiments and were analyzed with one-way ANOVA using Graphpad PRISM Version 5.0. Data was shown as the means \pm standard deviations (SD). Differences were considered statically significant if $P$-value was less than 0.05 $\left({ }^{*} P<0.05 ;{ }^{* *} P<0.01 ; * * * * 0<0.001\right)$.

\section{Results}

The role of endocytosis in EMCV replication in BHK-21 cells To elucidate whether the endocytic pathway correlated with EMCV replication in BHK-21 cells, endocytosis specific inhibitors were used. The suitable non-toxic concentration of $\mathrm{NH}_{4} \mathrm{Cl}$ and Bafilomycin $\mathrm{A} 1$ were measured by the CellTiter $96^{\circledR}$ Aqueous Non-Radioactive Cell Proliferation Assay kit (Fig. 1d, h).

Previous research communicates that $\mathrm{NH}_{4} \mathrm{Cl}$ can hamper the endosomal entry of viruses by preventing $\mathrm{pH}$-dependent activation of the fusion protein and by blocking membrane fusion [27]. In this experiment,
BHK-21 cells were first treated with $\mathrm{NH}_{4} \mathrm{Cl}$ and then incubated with the virus. Afterwards; the media was changed to remove unbound viruses. EMCV-infected cells or culture fluids were harvested at $9 \mathrm{~h}$ post infection. As shown in Fig. 1a-c, we found that expression of VP1, EMCV-3D and virus titer were significantly decreased in infected cells compared to control cells in dose dependent manner. This indicated that EMCV infection is sensitive to inhibition of endosomal acidification.

Another inhibitor of endocytic compartment acidification, bafilomycin A1, was also tested [28]. Our results showed that $10 \mathrm{nM}$ of bafilomycin A1 cannot block virus replication, while $20 \mathrm{nM}$ of bafilomycin A1 can inhibit the proliferation of EMCV (Fig. 1e-g).

Next, we examined which endocytic pathway, including the clathrin-dependent pathway, macropinocytosis and caveolea-dependent pathway [12, 29], was utilized by EMCV to infect BHK-21 cells.

\section{Clathrin-mediated endocytosis is not involved in EMCV replication in BHK-21 cells}

As Clathrin-mediated endocytosis is often related to endosomal acidification [30] and is a classical pathway for most viruses to enter into host cells [11]. Therefore, we next detected whether EMCV enters into BHK-21 cells through clathrin-mediated endocytosis by using chlorpromazine and Pitstop-2 inhibitors [31, 32]. The

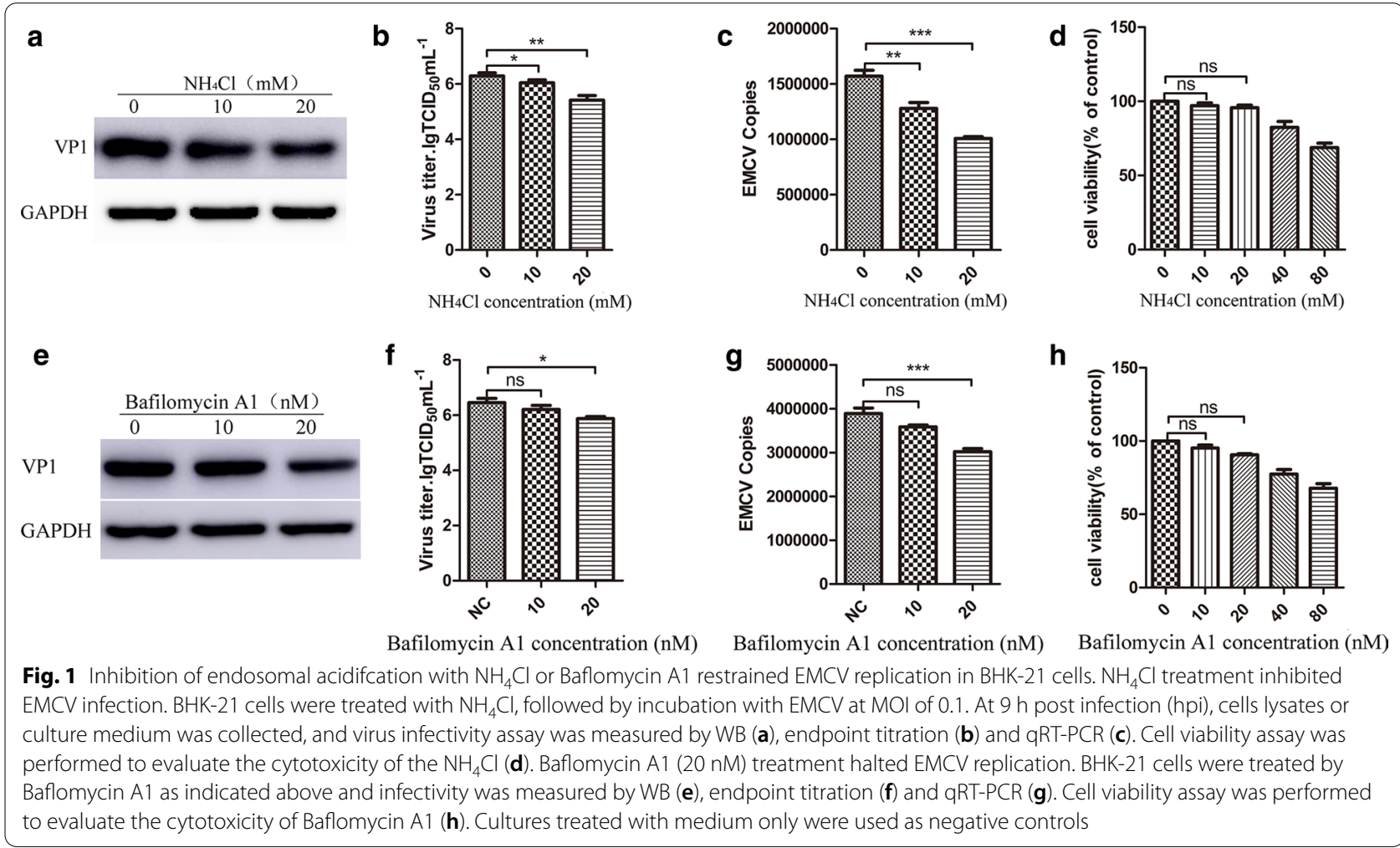


desirable non-toxic concentration of inhibitors for cells was achieved as indicated (Fig. 2c, f). Analysis indicated that neither the expression of EMCV-VP1 (Fig. 2a, b) nor virus titer assays (Fig. 2d, e) were affected by chlorpromazine or Pitstop-2.

\section{EMCV replication in BHK-21 cells is independent of macropinocytosis}

To check whether the virus replication is macropinocytosis-mediated, BHK-21 cells were treated with $\mathrm{NA}^{+} / \mathrm{H}^{+}$ exchanger inhibitor EIPA, Pak-1 inhibitor (1,1'-Dithiobis2-naphthalenol, IPA-3), and PI3K inhibitor, wortmannin [33]. Virus infectivity assay showed that none of them affected virus replication (Fig. 3a, b, c, e, f, g, i, j, k).

\section{Caveolae is required for EMCV replication in BHK-21 cells}

Next, we investigated whether the caveolae-dependent pathway was involved in EMCV infection. Caveolae is rich in cholesterol and sphingolipids and can be disrupted by nystatin or $M \beta C D$ [29]. The suitable non-toxic concentration was established (Fig. 4d, h). Results indicated that non-infected cell cultures when treated with certain concentration of nystatin $(12.5 \mu \mathrm{g} / \mathrm{ml}, 25 \mu \mathrm{g} /$ $\mathrm{ml})$ and $\mathrm{M} \beta \mathrm{CD}$ (2.5 mM, $5 \mathrm{mM}$ ) significantly inhibited EMCV proliferation (Fig. 4a, b, c, e, f and g). However, their effect on already infected EMCV-cell cultures was not significant (Fig. 4i-l).

\section{Caveolin-1 facilitates EMCV infection}

Caveolin-1 is the main structural protein of caveolae and is associated with the internalization of many viruses into their respective hosts [35]. In order to explore whether EMCV exploits caveolin-1 during its infection, the expression of caveolin-1 during EMCV infection was investigated. WB analysis indicated that caveolin-1 expression was increased in infected cells in a timedependent manner, consistent with the expression of the EMCV VP1 protein (Fig. 5a).

To further investigate the impact of caveolin-1 on EMCV infection, overexpression of caveolin-1 was carried out in relation to EGFP and BHK-21 cells (Fig. 5b). BHK-Cav1 and BHK-EGFP cells were cultured in medium without puromycin at least for 2 weeks prior to EMCV infection. Then BHK-Cav1, BHK-EGFP and BHK21 cells were incubated with $0.1 \mathrm{MOI} E M C V$ at $37^{\circ} \mathrm{C}$ for

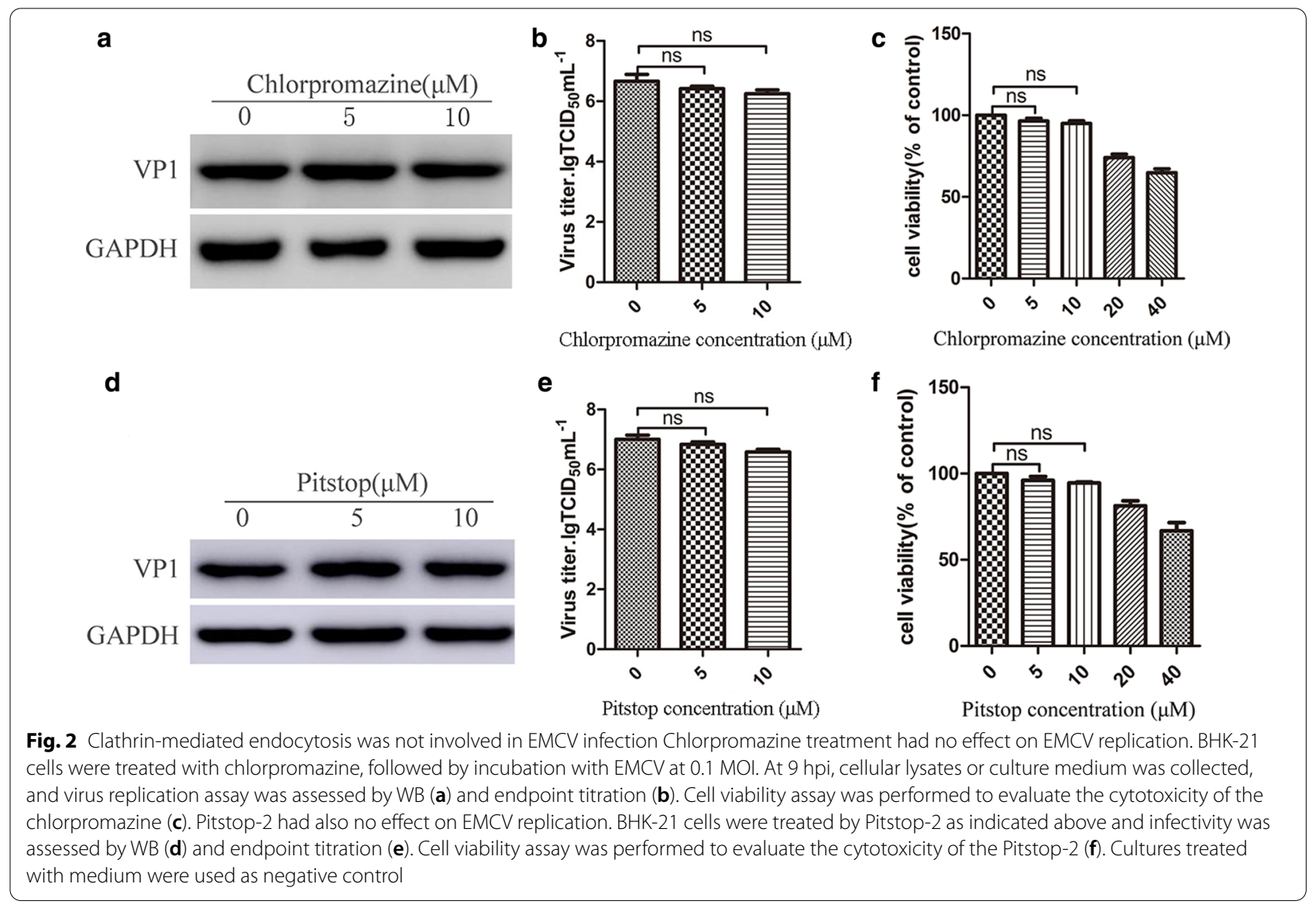




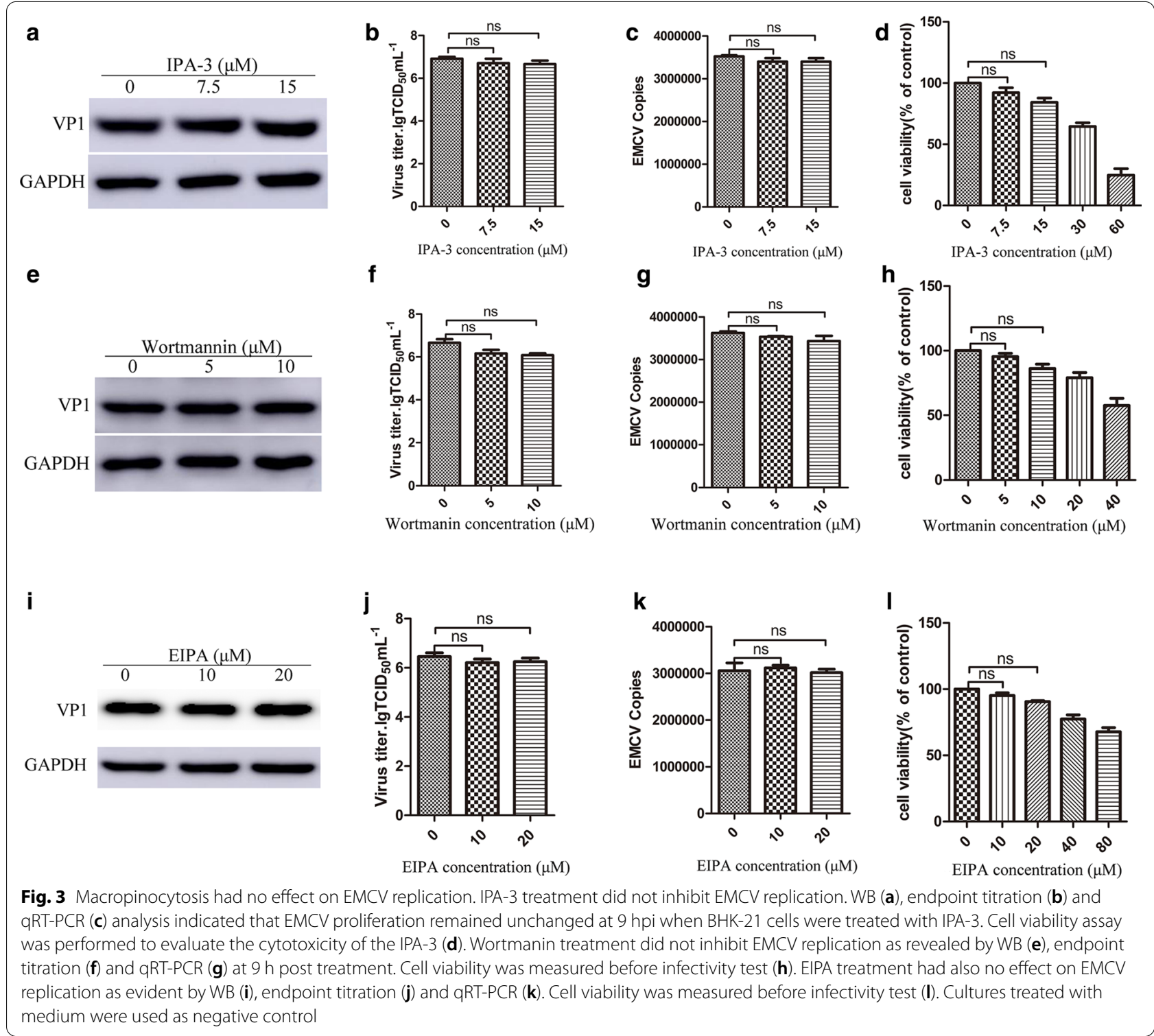

$1 \mathrm{~h}$ and cells were harvested for WB analyses at $12 \mathrm{~h}$ post infection.

As shown in Fig. 5b, the expression of VP1 was significantly higher in BHK-Cav1 cells compared to control cells. In order to confirm that EMCV replication is truly upregulated by the overexpression of caveolin-1, culture supernatants were collected at 3-h interval, and viral titers were determined as described previously [24]. The growth kinetics experiment showed that the overall process of virus replication was more efficient in BHK-Cav1 than in BHK-21 and BHK-EGFP cells (Fig. 5c).

For a more in depth understanding of the molecular pathogenesis of EMCV infection in vitro, knockdown experiments using specific or control siRNA sequences were conducted. RNA interference silenced caveolin-1 expression in BHK-21 cells, in turn, impacted viral infection process as evident by the expression of VP1 (Fig. 5d), virus titers (Fig. 5e) and virus copies number (Fig. 5f).

To further elaborate caveolin-1involvement in the infection process, the same siRNA experiment was repeated in BHK-Cav1 cells. Results indicated that downregulation of caveolin-1 significantly inhibited the virus replication in BHK-Cav1 cells (Fig. 5g-i).

\section{Caveolin-1 is essential for EMCV infection by involving in internalization}

To ensure the effect of caveolin-1, we examined the colocalization of virus with caveolin-1 by confocal imaging. 


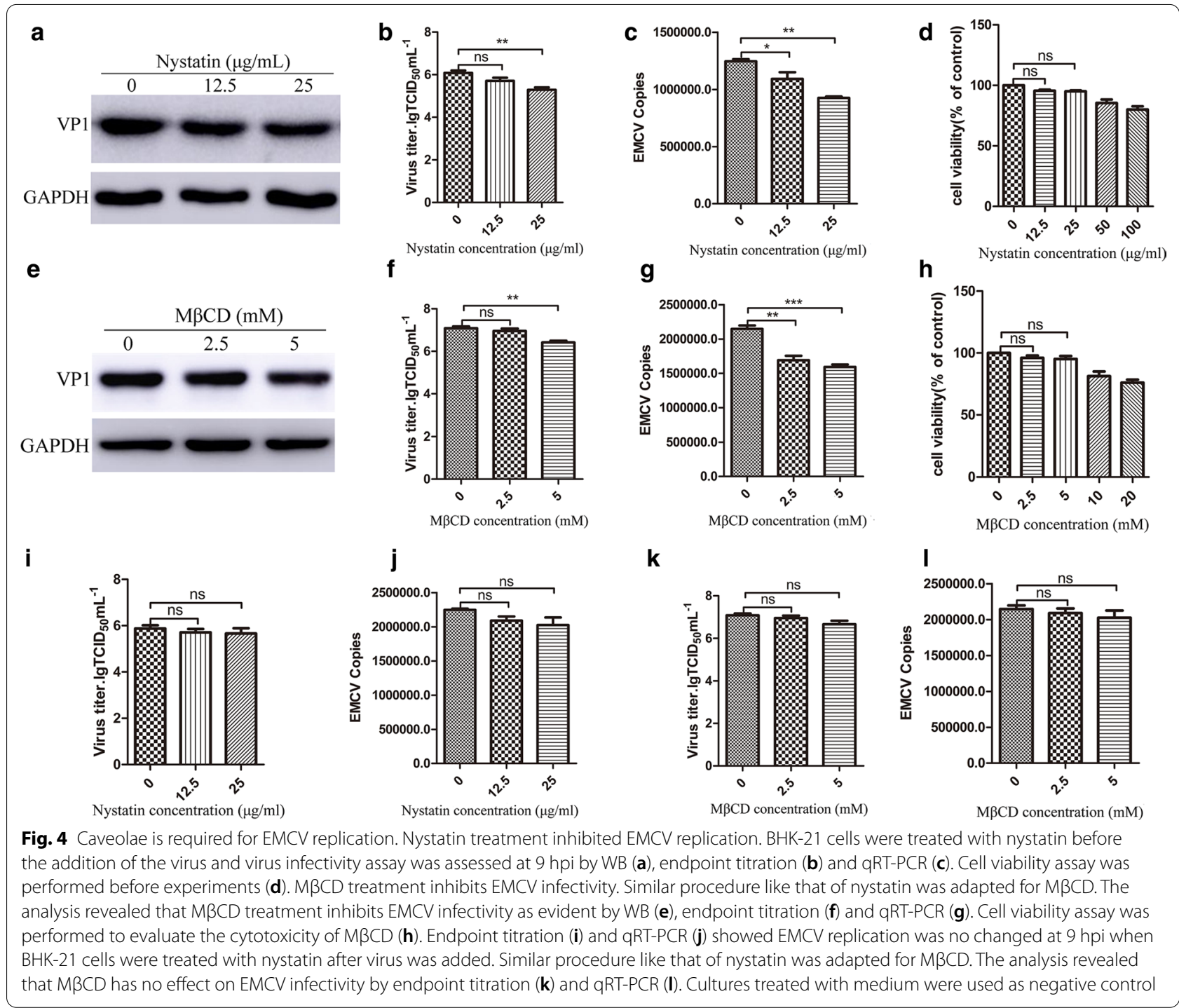

As shown in Fig. 6a, after exposed to the EMCV for 120 min, EMCV-VP1 co-localized with caveolin-1 could be observed in infected BHK-21 cells.

As EMCV-VP1 co-localized with caveolin-1 at $120 \mathrm{~min}$ post infection, we next investigated caveolin-1 association with EMCV internalization. Increased EMCV internalization efficiency was noticed in BHK-Cav1 as compared to BHK-EGFP or BHK-21 cells (Fig. 6b, c). Consistent with the results of caveolin-1 overexpression, siRNAs that effectively restrained caveolin- 1 expression and inhibited the EMCV internalization $(P<0.01)$ as compared to control (Fig. 6d, e).

\section{Dynamin is needed for EMCV replication in BHK-21 cells}

Dynamin is a kind of large GTPase that can promote the split of endocytic membranes [12] and is considered to have a role in both clathrin-dependent endocytosis and several other endocytic pathways [34]. Therefore, we investigated its potential role in EMCV replication. Two inhibitors of GTPase activity, dynasore [35, 36] and the lipid-binding mitmab were selected [37], and their optimal concentrations were obtained by cell viability assay (Fig. 7d, h). Results indicated that these inhibitors significantly inhibited virus replication in BHK-21 before infection when introduced before infection (Fig. 7a, b, c, e, f and g) but their effect on infected cells was not significant when added after infection (Fig. 7i-l).

\section{Role of actin in EMCV infection in BHK-21 cells}

Results of the current study suggested that EMCV infection in BHK-21 cells is mediated by caveolin- and dynamin-dependent endocytosis. Next, the role of the 


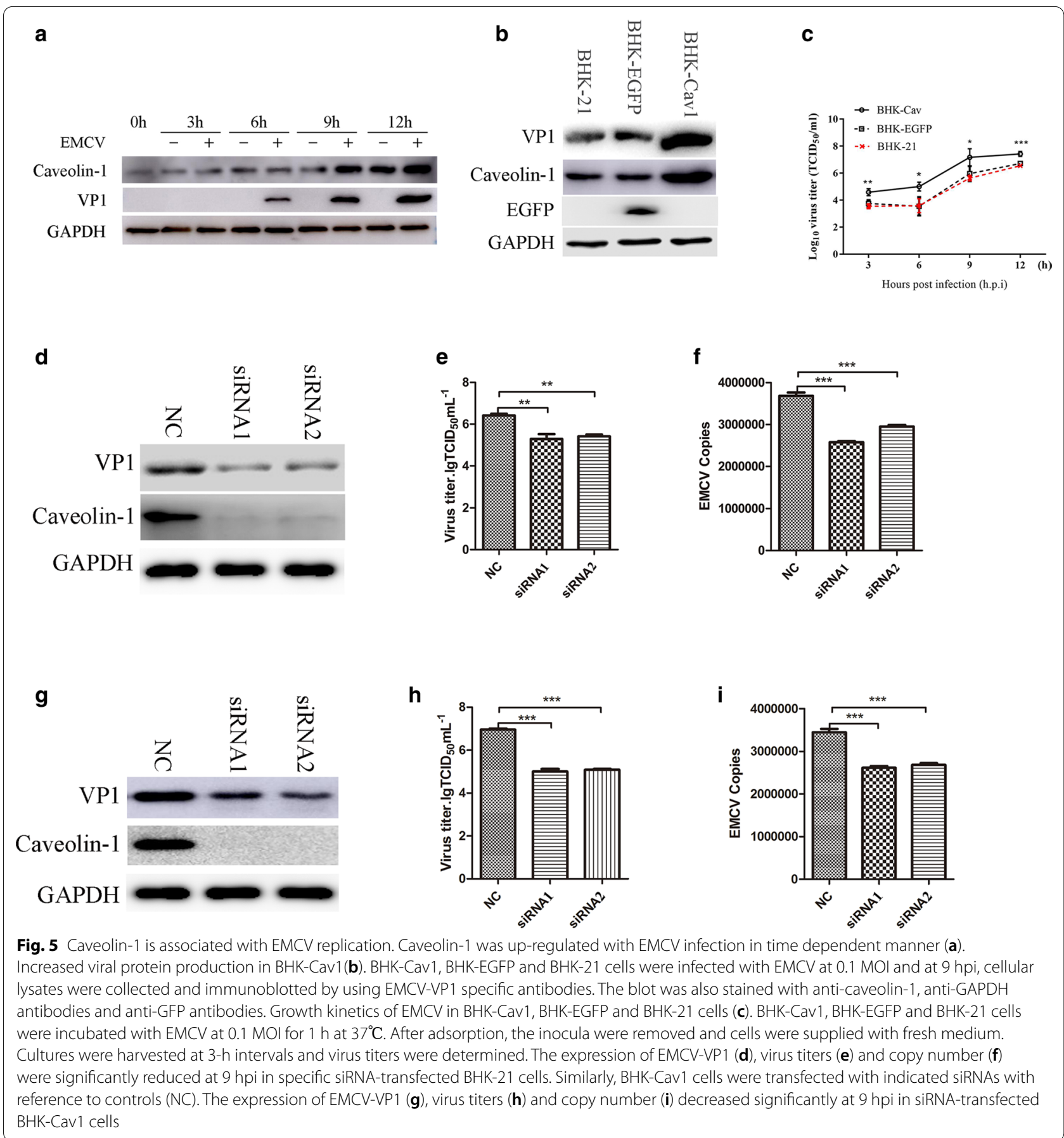

cytoskeleton during virus entry was examined by actin disrupting agent (cytochalasin D) and stabilizing compound (jasplakinolide) [38, 39]. The optimal concentrations of these two inhibitors were obtained by cell viability assay (Fig. 8d, h). We found that both actinstabilizing jasplakinolide and actin-disrupting agent cytochalasin D significantly halted EMCV infection when introduced into cells before infection (Fig. 8a, b, c, e, f and g). However, the post-infected treatment was not significant (Fig. 8i-l).

\section{Discussion}

Endocytosis is an important cellular process that mediates nutrient uptake, receptor internalization and the regulation of cell signaling (Endocytosis in proliferating, quiescent and terminally differentiated cells. 2018). 


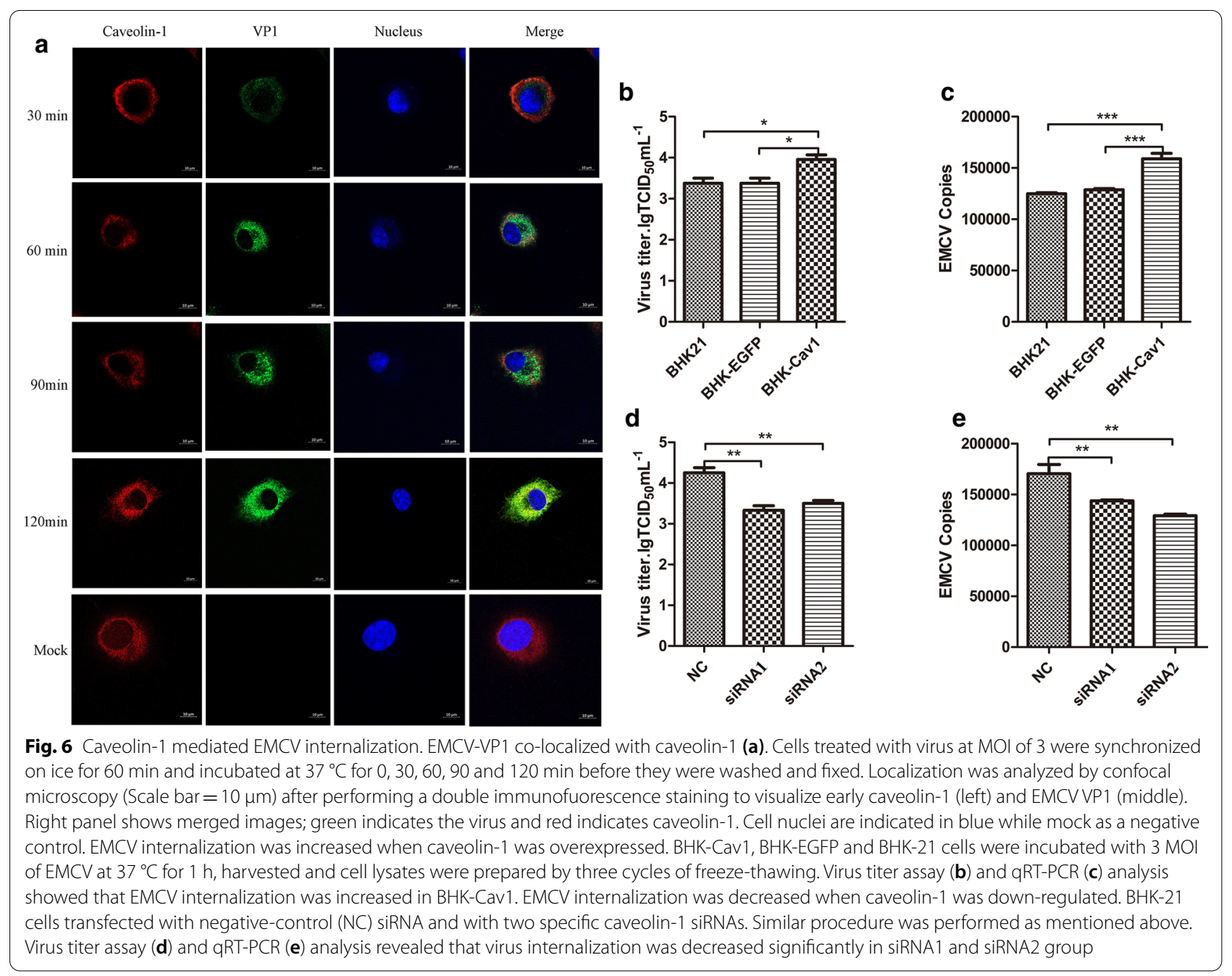

For a large number of viruses, they can take advantage of the endocytosis machinery for infecting humans and animals (Endocytosis of Viruses and Bacteria, Pascale Cossart and Ari Helenius). Previous studies showed that members of Picornaviridae family use different endocytic mechanisms for entry into host cells $[12,15,17,19,20]$. However, the mechanisms involved in internalization of EMCV are poorly understand.

In the current study, we investigated the role of endocytosis in EMCV infection in BHK-21 cells. Lysosomotropic agents sensitivity is considered a good evidence of endocytosis [40]; therefore, we pretreated cells with different inhibitors $\left(\mathrm{NH}_{4} \mathrm{Cl}\right.$ or Baflomycin A1) of endosome acidification. Both reagents partly inhibited the virus infectivity (Fig. 1), suggesting that endocytosis has a role in EMCV infection.

Earlier studies on both enveloped and nonenveloped viruses, such as HIV [41], adenovirus [42], foot-andmouth disease virus [43], reovirus [44] and bluetongue virus $[45,46]$, document that the virus entry into their respective host cells is by clathrin-mediated pathway. But results of our study indicated that neither viral structural proteins nor virus titers were significantly decreased by treatment of cells with clathrin specific inhibitors (Fig. 2a, $\mathrm{b}, \mathrm{d}, \mathrm{e})$ suggesting that clathrin-mediated endocytosis might not be an essential pathway for EMCV infection.

As one of the endocytic mechanisms in mammalian cells, macropinocytosis involves internalization of large number of plasma membrane together with extracellular medium and forms micropinosome [47]. Many intracellular pathogens by host cells via macropinocytosis have been described. Some viruses, such as African swine fever virus (ASFV) [48], Ebola virus [49] and Human cytomegalovirus (HCMV) [50], use this pathway to gain access to host cell [47]. Then we supposed whether macropinocytosis-dependent pathway may be involved in EMCV infection and hence first, cells were pretreated with macropinocytosis specific inhibitor 


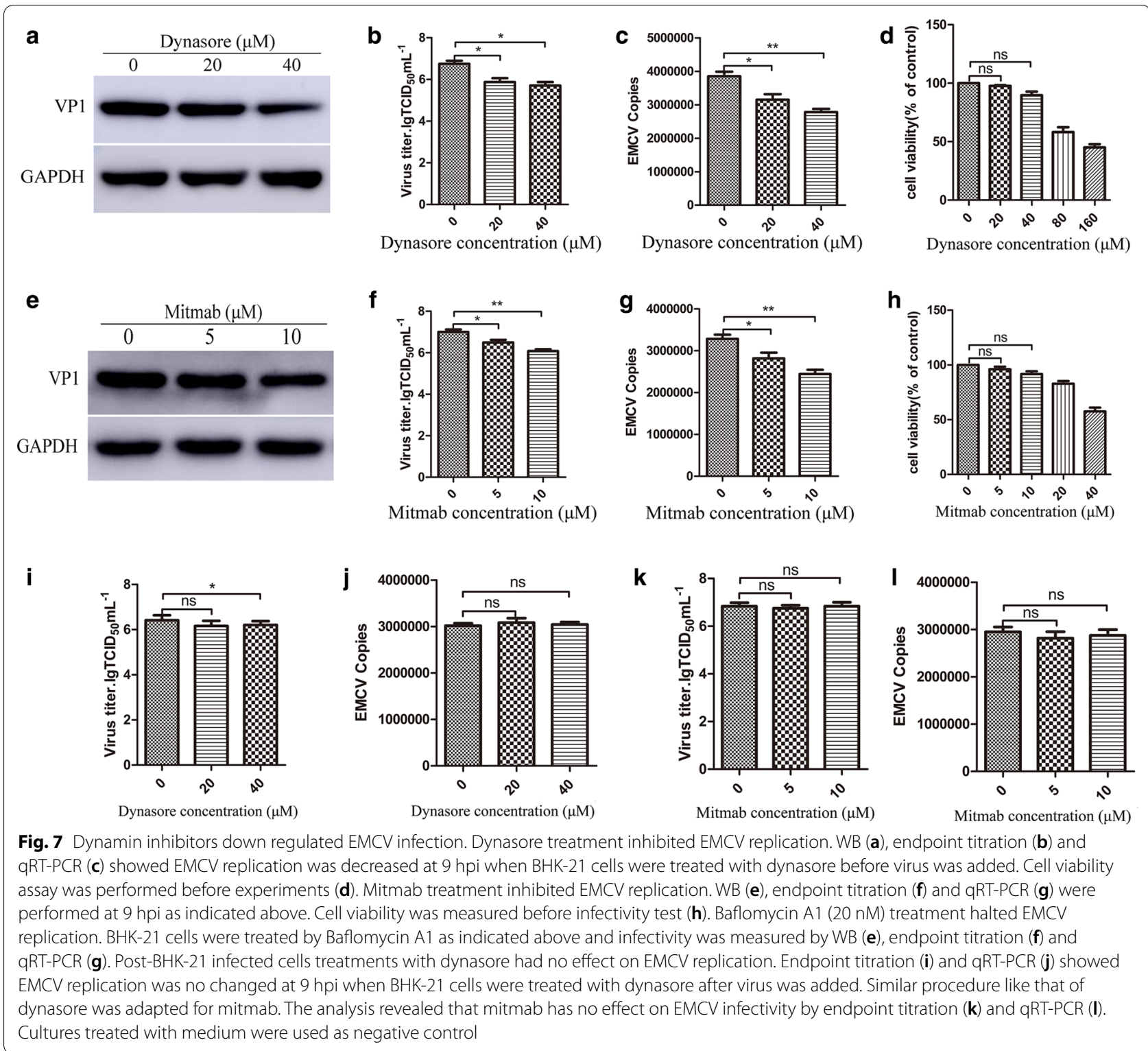

such as EIPA, IPA-3, wortmannin and then infected with the EMCV. Our results showed that these inhibitors did not affect EMCV infectivity assay (Fig. 3a, b, c, $\mathrm{e}, \mathrm{f}, \mathrm{g}, \mathrm{i}, \mathrm{j}, \mathrm{k}$ ) and thus implies that macropinocytosis is not involved in EMCV infection in vitro.

Apart from clathrin-dependent endocytosis, lipid raft and caveolae-dependent endocytosis are alternative endocytic pathways proposed for viruses intake [51]. It has been reported that $M B C D$ could inhibit the CAV9 infection via lipid microdomains [52], therefore, we examined the role of caveolar/lipid rafts endocytosis in EMCV infection in BHK-21 cells. We found that EMCV infection significantly decreased in $M \beta C D$ and nystatin treated cells compared to control before incubated with EMCV (Fig. 4a, b, c, e, f, g), while their effect was limited when added after infection (Fig. $4 \mathrm{i}-\mathrm{l}$ ). These results indicated that caveolae is involved in early stage of EMCV replication.

Caveolin-1 is the main structural protein of caveolae and has various functions in endosomal membrane traffic and other cellular processes, such as endocytosis, signal transductions, protein trafficking and secretion [53-56]. Additionally, caveolin-1 is also involved in many viruses entry process, such as HIV [57], aquareoviruses [58], coronavirus [59], HCV [60], RSV [61] and CSFV [62]. The dependence of EMCV infection on caveolae-dependent 


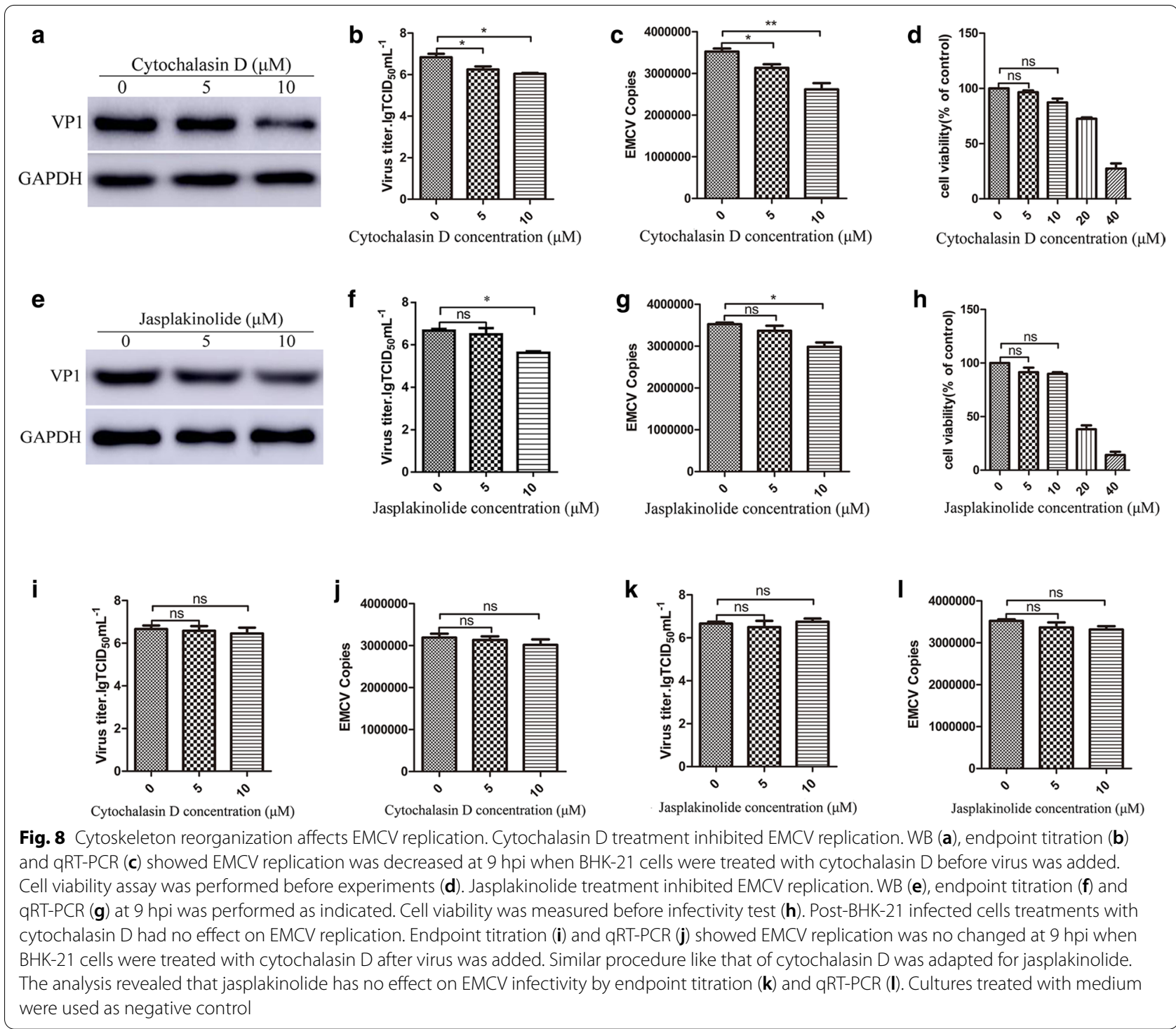

pathway and the findings that EMCV infection corresponds to caveolin-1 expression level (Fig. 5a), directed us to study whether caveolin-1 is an important element involved in the replication process of the virus. To access the possibility, the lentiviral vector overexpressed caveolin-1 and siRNA targeted caveolin-1 were constructed. It is evident when overexpression of caveolin-1 resulted in a clear increase in the infection efficiency compared to the control cells (Fig. 5b, c). Conversely, decreased expression of caveolin-1 by siRNA, inhibited the virus replication in BHK-21 cells (Fig. $5 \mathrm{~d}-\mathrm{i}$ ). The results highlight the importance of caveolin-1 for EMCV infection in BHK-21 cells.

Entry of viruses into permissive cells is an important stage in the viral pathogenesis $[11,51]$ and different viruses exploit various cellular endocytic mechanisms to initiate internalization and infection [63]. Results of the co-localization experiment in the current study at different time intervals suggested that there was co-localization of EMCV-VP1 and caveolin-1 at $120 \mathrm{~min}$ post infection (Fig. 6a) which implies that that caveolin-1 is required for early stage of EMCV replication. Further, EMCV internalization was enhanced by overexpression of caveolin-1 (Fig. 6b, c) while EMCV internalization was strongly inhibited when caveolin-1 was downregulated (Fig. 6d, e). These findings, together with the results of co-localization (Fig. 6a) indicated that caveolin-1 is required for the internalization and infection of EMCV in vitro.

Previous studies have pointed out that either overexpressed dominant-negative mutants of dynamin or 
disrupted actin assembly can block caveolae-mediated endocytosis $[29,64]$. Therefore, we studied the potential role of dynamin and actin in EMCV infection in BHK21 cells using two inhibitors of dynamin (dynasore and mitmab). Both inhibitors affected virus replication when added before infection (Fig. 7a, b, c, e, f and g). However, neither dynasore nor mitmab blocked EMCV infection when added after infection (Fig. 7i-l). Together, these results suggest that dynamin plays an exclusive role in virus uptake and thereby mediating infectivity.

It has been known that cytochalasin D inhibits actin subunits polymerization, whereas jasplakinolide inhibits the polymerization to stabilize the filaments $[38,65,66]$ and we implemented this observation to determine their role in EMCV infection. We discovered that virus replication was decreased in cells pretreated with cytochalasin $\mathrm{D}$ and jasplakinolide (Fig. 8a, b, c, e, f and g) but their effect was limited when added after infection (Fig. 8i-l). This revealed that both actin filaments and actin reorganization are required for EMCV infection in vitro.

\section{Conclusion}

In conclusion, the present study demonstrates for the first time that caveolin-1, dynamin and actin-dependent endocytosis pathways are involved in EMCV uptake, internalization and its subsequent replication in BHK-21 cells in vitro. Remarkably, there is a positive correlation between expression level of caveolin-1 and EMCV replication in vitro. Further work is needed to investigate the role of phosphorylation of caveolin-1, and the related singling pathway in regulating EMCV entry and replication.

\section{Abbreviations \\ EMCV: encephalomyocarditis virus; DMEM: Dulbecco's modified eagle medium; FBS: fetal bovine serum; MEM: minimum essential medium; PFU: plaque-forming unit; WB: western blotting; mAb: monoclonal antibody; $\mathrm{pAb}$ : polyclonal antibody; qRT-PCR: quantitative reverse transcription polymerase chain reaction; IFA: indirect immunofluorescence assay; DAPI: 4,6-diamidino- 2-phenylindole; MOl: multiplicity of infection; hpi: hour post infection.}

\section{Acknowledgements}

We thank Dr. Enqi Du (Northwest A\&F University, China) for providing the replication-defective lentivirus system; Dr. Juan Bai (Nanjing Agricultural University, China) for his kindly supplied the EMCV-VP1 mAb, Prof. Zulqarnain Baloch for critical reading of our manuscript.

\section{Authors' contributions \\ Jialin Bai were the project leader, Qiongyi Li were responsible for experimental and project design. Qiongyi Li and Yang Liu performed most of the experi- ments. Shujuan Xu and Kexue Zhao performed some of the experiments. Ying Ling and Rongxiu Liu prepared the samples. Data analysis was performed by Qiongyi Li and Yang Liu. The paper was written by Qiongyi Li, revised and proofread by Amjad Ali.}

\section{Funding}

This work is supported by the National Natural Science Foundation of China (31702234, 31860696), the Fundamental Research Funds for the Central Universities in the Northwest Minzu University (31920180123, 31920190003), the project of Talent introduction for NWMU (No. xbmuyjrc201627); funds from Gansu Education Departmentand (2018B-018); the program for Changjiang Scholars and Innovative Research Team in University (IRT_17R88).

Availability of data and materials

All data included in the manuscript are available.

Ethics approval and consent to participate

Not applicable.

\section{Consent for publication}

Not applicable.

\section{Competing interests}

The authors declare that there is no conflict of interest.

\section{Author details}

${ }^{1}$ Biomedical Research Center, Key Laboratory of Biotechnology and Bioengineering of State Ethnic Affairs Commission, Northwest Minzu University, Lanzhou, China. ${ }^{2}$ College of Life Science and Engineering, Northwest Minzu University, Lanzhou, China.

Received: 23 October 2020 Accepted: 2 March 2021

Published online: 24 March 2021

\section{References}

1. Matthews RE. The classification and nomenclature of viruses. Summary of results of meetings of the International Committee on Taxonomy of Viruses in The Hague, September 1978. Intervirology. 1979. https://doi. org/10.1159/000149025.

2. Carocci M, Bakkali-Kassimi L. The encephalomyocarditis virus. Virulence. 2012. https://doi.org/10.4161/viru.20573.

3. Helwig FC, Schmidt CH. A filter-passing agent producing interstitial myocarditis in anthropoid apes and small animals. Science. 1945. https:// doi.org/10.1126/science.102.2637.31.

4. Canelli E, Luppi A, Lavazza A, Lelli D, Sozzi E, Martin AM, Gelmetti D, Pascotto E, Sandri C, Magnone W, Cordioli P. Encephalomyocarditis virus infection in an Italian zoo. Virol J. 2010. https://doi.org/10.1186/ 1743-422X-7-64.

5. Maurice H, Nielen M, Brocchi E, Nowotny N, Kassimi LB, Billinis C, Loukaides P, O'Hara RS, Koenen F. The occurrence of encephalomyocarditis virus (EMCV) in European pigs from 1990 to 2001. Epidemiol Infect. 2005. https://doi.org/10.1017/s0950268804003668.

6. Reddacliff LA, Kirkland PD, Hartley WJ, Reece RL. Encephalomyocarditis virus infections in an Australian zoo. J Zoo Wildl Med. 1997;28:153-7.

7. Billinis C. Encephalomyocarditis virus infection in wildlife species in Greece. JWildl Dis. 2009. https://doi.org/10.7589/0090-3558-45.2.522.

8. Bazzone LE, King M, MacKay CR, Kyawe PP, Meraner P, Lindstrom D, RojasQuintero J, Owen CA, Wang JP, Brass AL, et al. A disintegrin and metalloproteinase 9 domain (ADAM9) is a major susceptibility factor in the early stages of encephalomyocarditis virus infection. MBio. 2019. https://doi. org/10.1128/mBio.02734-18.

9. Zhu Q, Tan P, Li Y, Lin M, Li C, Mao J, Cui J, Zhao W, Wang HY, Wang RF. DHX29 functions as an RNA co-sensor for MDA5-mediated EMCV-specific antiviral immunity. PLoS Pathog. 2018. https://doi.org/10.1371/journal. ppat.1006886.

10. Burkard C, Verheije MH, Wicht O, van Kasteren SI, van Kuppeveld FJ, Haagmans BL, Pelkmans L, Rottier PJ, Bosch BJ, de Haan CA. Coronavirus cell entry occurs through the endo-/lysosomal pathway in a proteolysisdependent manner. PLoS Pathog. 2014. https://doi.org/10.1371/journal. ppat.1004502.

11. Marsh M, Helenius A. Virus entry: open sesame. Cell. 2006. https://doi.org/ 10.1016/j.cell.2006.02.007.

12. Heikkila O, Susi P, Tevaluoto T, Harma H, Marjomaki V, Hyypia T, Kiljunen S. Internalization of coxsackievirus A9 is mediated by \{beta\}2-microglobulin, dynamin, and Arf6 but not by caveolin-1 or clathrin. JVirol. 2010. https:// doi.org/10.1128/JVI.01340-09.

13. Pietiainen V, Marjomaki V, Upla P, Pelkmans L, Helenius A, Hyypia T. Echovirus 1 endocytosis into caveosomes requires lipid rafts, dynamin II, 
and signaling events. Mol Biol Cell. 2004. https://doi.org/10.1091/mbc e04-01-0070.

14. Bergelson JM. New (fluorescent) light on poliovirus entry. Trends Microbiol. 2008. https://doi.org/10.1016/j.tim.2007.12.004.

15. Brandenburg B, Lee LY, Lakadamyali M, Rust MJ, Zhuang X, Hogle JM. Imaging poliovirus entry in live cells. PLoS Biol. 2007. https://doi.org/10. 1371/journal.pbio.0050183.

16. Coyne CB, Kim KS, Bergelson JM. Poliovirus entry into human brain microvascular cells requires receptor-induced activation of SHP-2. EMBO J. 2007. https://doi.org/10.1038/sj.emboj.7601831.

17. Chung SK, Kim JY, Kim IB, Park SI, Paek KH, Nam JH. Internalization and trafficking mechanisms of coxsackievirus B3 in HeLa cells. Virology. 2005. https://doi.org/10.1016/j.virol.2004.12.010.

18. Berryman S, Clark S, Monaghan P, Jackson T. Early events in integrin alphavbeta6-mediated cell entry of foot-and-mouth disease virus. J Virol. 2005. https://doi.org/10.1128/JVl.79.13.8519-8534.2005.

19. Dicara D, Burman A, Clark S, Berryman S, Howard MJ, Hart IR, Marshall JF, Jackson T. Foot-and-mouth disease virus forms a highly stable, EDTA-resistant complex with its principal receptor, integrin alphavbeta6: implications for infectiousness. JVirol. 2008. https://doi.org/10.1128/JVI. 01480-07.

20. Johns HL, Berryman S, Monaghan P, Belsham GJ, Jackson T. A dominantnegative mutant of rab5 inhibits infection of cells by foot-and-mouth disease virus: implications for virus entry. J Virol. 2009. https://doi.org/10. 1128/JVI.02460-08.

21. Quinting B, Robert B, Letellier C, Boxus M, Kerkhofs P, Schynts F, Collard A. Development of a 1-step enzyme-linked immunosorbent assay for the rapid diagnosis of bovine respiratory syncytial virus in postmortem specimens. JVet Diagn Invest. 2007. https://doi.org/10.1177/1040638707 01900302.

22. Huang J, Li J, Cheng C, Tang X, Shen X, Hao B. An amino acid duplication/ insertion in the Bm126 gene of Bombyx mori nucleopolyhedrovirus alters viral gene expression as shown by differential gene expression analysis. Arch Virol. 2019. https://doi.org/10.1007/s00705-018-04144-2.

23. Du E, Tikoo SK. Efficient replication and generation of recombinant bovine adenovirus-3 in nonbovine cotton rat lung cells expressing I-Scel endonuclease. J Gene Med. 2010. https://doi.org/10.1002/jgm.1505.

24. Dorobantu CM, Albulescu L, Harak C, Feng Q, van Kampen M, Strating JR, Gorbalenya AE, Lohmann V, van der Schaar HM, van Kuppeveld FJ. Modulation of the host lipid landscape to promote RNA virus replication: the picornavirus encephalomyocarditis virus converges on the pathway used by hepatitis C virus. PLoS Pathog. 2015. https://doi.org/10.1371/journal. ppat.1005185.

25. Szczepanski A, Owczarek K, Milewska A, Baster Z, Rajfur Z, Mitchell JA, Pyrc K. Canine respiratory coronavirus employs caveolin-1-mediated pathway for internalization to HRT-18G cells. Vet Res. 2018. https://doi. org/10.1186/s13567-018-0551-9.

26. Zhang YN, Liu YY, Xiao FC, Liu CC, Liang XD, Chen J, Zhou J, Baloch AS, Kan L, Zhou B, Qiu HJ. Rab5, Rab7, and Rab11 are required for caveoladependent endocytosis of classical swine fever virus in porcine alveolar macrophages. JVirol. 2018. https://doi.org/10.1128/JVI.00797-18.

27. Qian Z, Dominguez SR, Holmes KV. Role of the spike glycoprotein of human middle east respiratory syndrome coronavirus (MERS-CoV) in virus entry and syncytia formation. PLoS ONE. 2013. https://doi.org/10. 1371/journal.pone.0076469.

28. Bowman EJ, Siebers A, Altendorf K. Bafilomycins: a class of inhibitors of membrane ATPases from microorganisms, animal cells, and plant cells. Proc Natl Acad Sci U S A. 1988. https://doi.org/10.1073/pnas.85.21.7972.

29. Pelkmans L, Helenius A. Endocytosis via caveolae. Traffic. 2002. https:// doi.org/10.1034/j.1600-0854.2002.30501.x.

30. Pelkmans L, Helenius A. Insider information: what viruses tell us about endocytosis. Curr Opin Cell Biol. 2003. https://doi.org/10.1016/s09550674(03)00081-4.

31. Phonphok Y, Rosenthal KS. Stabilization of clathrin coated vesicles by amantadine, tromantadine and other hydrophobic amines. FEBS Lett. 1991. https://doi.org/10.1016/0014-5793(91)80390-o.

32. Wang $L H$, Rothberg KG, Anderson RG. Mis-assembly of clathrin lattices on endosomes reveals a regulatory switch for coated pit formation. J Cell Biol. 1993. https://doi.org/10.1083/jcb.123.5.1107.
33. Lim JP, Gleeson PA. Macropinocytosis: an endocytic pathway for internalising large gulps. Immunol Cell Biol. 2011. https://doi.org/10.1038/icb. 2011.20.

34. Doherty GJ, McMahon HT. Mechanisms of endocytosis. Annu Rev Biochem. 2009. https://doi.org/10.1146/annurev.biochem.78.081307.110540.

35. Hill TA, Mariana A, Gordon CP, Odell LR, Robertson MJ, McGeachie AB, Chau N, Daniel JA, Gorgani NN, Robinson PJ, McCluskey A. Iminochromene inhibitors of dynamins I and II GTPase activity and endocytosis. J Med Chem. 2010. https://doi.org/10.1021/jm100119c

36. Preta G, Cronin JG, Sheldon IM. Dynasore-not just a dynamin inhibitor. Cell Commun Signal. 2015. https://doi.org/10.1186/s12964-015-0102-1.

37. Quan A, McGeachie AB, Keating DJ, van Dam EM, Rusak J, Chau N, Malladi CS, Chen C, McCluskey A, Cousin MA, Robinson PJ. Myristyl trimethyl ammonium bromide and octadecyl trimethyl ammonium bromide are surface-active small molecule dynamin inhibitors that block endocytosis mediated by dynamin I or dynamin II. Mol Pharmacol. 2007. https://doi. org/10.1124/mol.107.034207.

38. Dietzel E, Kolesnikova L, Maisner A. Actin filaments disruption and stabilization affect measles virus maturation by different mechanisms. Virol J. 2013. https://doi.org/10.1186/1743-422X-10-249.

39. Samson F, Donoso JA, Heller-Bettinger I, Watson D, Himes RH. Nocodazole action on tubulin assembly, axonal ultrastructure and fast axoplasmic transport. J Pharmacol Exp Ther. 1979;208:411-7.

40. Hernaez B, Alonso C. Dynamin- and clathrin-dependent endocytosis in African swine fever virus entry. JVirol. 2010. https://doi.org/10.1128/JVI. 01557-09.

41. Daecke J, Fackler OT, Dittmar MT, Krausslich HG. Involvement of clathrinmediated endocytosis in human immunodeficiency virus type 1 entry. J Virol. 2005. https://doi.org/10.1128/JVl.79.3.1581-1594.2005.

42. Wang K, Huang S, Kapoor-Munshi A, Nemerow G. Adenovirus internalization and infection require dynamin. JVirol. 1998:72:3455-8.

43. O'Donnell V, LaRocco M, Duque H, Baxt B. Analysis of foot-and-mouth disease virus internalization events in cultured cells. J Virol. 2005. https:// doi.org/10.1128/JVI.79.13.8506-8518.2005.

44. Maginnis MS, Mainou BA, Derdowski A, Johnson EM, Zent R, Dermody TS, NPXY motifs in the beta1 integrin cytoplasmic tail are required for functional reovirus entry. J Virol. 2008. https://doi.org/10.1128/JVI.01612-07.

45. Patel A, Mohl BP, Roy P. Entry of bluetongue virus capsid requires the late endosome-specific lipid lysobisphosphatidic acid. J Biol Chem. 2016. https://doi.org/10.1074/jbc.M115.700856.

46. Forzan M, Marsh M, Roy P. Bluetongue virus entry into cells. J Virol. 2007. https://doi.org/10.1128/JVI.02284-06.

47. de Carvalho TM, Barrias ES, de Souza W. Macropinocytosis: a pathway to protozoan infection. Front Physiol. 2015. https://doi.org/10.3389/fphys. 2015.00106.

48. Andrés $G$. African swine fever virus gets undressed: new insights on the entry pathway. J Virol. 2017. https://doi.org/10.1128/JVI.01906-16.

49. Aleksandrowicz P, Marzi A, Biedenkopf N, Beimforde N, Becker S, Hoenen T, Feldmann H, Schnittler HJ. Ebola virus enters host cells by macropinocytosis and clathrin-mediated endocytosis. J Infect Dis. 2011. https://doi. org/10.1093/infdis/jir326.

50. Lee JH, Pasquarella JR, Kalejta RF. Cell line models for human cytomegalovirus latency faithfully mimic viral entry by macropinocytosis and endocytosis. J Virol. 2019. https://doi.org/10.1128/JVI.01021-19.

51. Mercer J, Schelhaas M, Helenius A. Virus entry by endocytosis. Annu Rev Biochem. 2010. https://doi.org/10.1146/annurev-bioch em-060208-104626.

52. Triantafilou K, Triantafilou M. Lipid raft microdomains: key sites for Coxsackievirus A9 infectious cycle. Virology. 2003. https://doi.org/10.1016/j. virol.2003.08.036

53. Lamaze C, Tardif N, Dewulf M, Vassilopoulos S, Blouin CM. The caveolae dress code: structure and signaling. Curr Opin Cell Biol. 2017. https://doi. org/10.1016/j.ceb.2017.02.014.

54. Henkhaus RS, Roy UK, Cavallo-Medved D, Sloane BF, Gerner EW, Ignatenko NA. Caveolin-1-mediated expression and secretion of kallikrein 6 in colon cancer cells. Neoplasia. 2008. https://doi.org/10.1593/neo. 07817.

55. Parton RG, Simons K. The multiple faces of caveolae. Nat Rev Mol Cell Biol. 2007. https://doi.org/10.1038/nrm2122. 
56. Uemura T, Tsaprailis G, Gerner EW. GSTPi stimulates caveolin-1-regulated polyamine uptake via actin remodeling. Oncotarget. 2019. https://doi. org/10.18632/oncotarget.27192.

57. Mergia A. The role of Caveolin 1 in HIV infection and pathogenesis. Viruses. 2017. https://doi.org/10.3390/v9060129.

58. Zhang F, Guo H, Zhang J, Chen Q, Fang Q. Identification of the caveolae/ raft-mediated endocytosis as the primary entry pathway for aquareovirus. Virology. 2018. https://doi.org/10.1016/j.virol.2017.09.019.

59. Owczarek K, Szczepanski A, Milewska A, Baster Z, Rajfur Z, Sarna M, Pyrc K. Early events during human coronavirus OC43 entry to the cell. Sci Rep. 2018. https://doi.org/10.1038/s41598-018-25640-0.

60. Kim JY, Wang L, Lee J, Ou JJ. Hepatitis C virus induces the localization of lipid rafts to autophagosomes for its RNA replication. J Virol. 2017. https:// doi.org/10.1128/JVI.00541-17.

61. Ludwig A, Nguyen TH, Leong D, Ravi LI, Tan BH, Sandin S, Sugrue RJ. Caveolae provide a specialized membrane environment for respiratory syncytial virus assembly. J Cell Sci. 2017. https://doi.org/10.1242/jcs. 198853.

62. Ning P, Gao L, Zhou Y, Hu C, Lin Z, Gong C, Guo K, Zhang X. Caveolin1-mediated endocytic pathway is involved in classical swine fever virus
Shimen infection of porcine alveolar macrophages. Vet Microbiol. 2016. https://doi.org/10.1016/j.vetmic.2016.09.016.

63. Mazzon M, Marsh M. Targeting viral entry as a strategy for broad-spectrum antivirals. F1000Res. 2019. https://doi.org/10.12688/f1000research. 19694.1.

64. Conner SD, Schmid SL. Regulated portals of entry into the cell. Nature. 2003. https://doi.org/10.1038/nature01451.

65. Wang JL, Zhang JL, Chen W, Xu XF, Gao N, Fan DY, An J. Roles of small GTPase Rac1 in the regulation of actin cytoskeleton during dengue virus infection. PLoS Negl Trop Dis. 2010. https://doi.org/10.1371/journal.pntd. 0000809.

66. Zhang J, Wu N, Gao N, Yan W, Sheng Z, Fan D, An J. Small G Rac1 is involved in replication cycle of dengue serotype 2 virus in EAhy926 cells via the regulation of actin cytoskeleton. Sci China Life Sci. 2016. https:// doi.org/10.1007/s11427-016-5042-5.

\section{Publisher's Note}

Springer Nature remains neutral with regard to jurisdictional claims in published maps and institutional affiliations.
Ready to submit your research? Choose BMC and benefit from:

- fast, convenient online submission

- thorough peer review by experienced researchers in your field

- rapid publication on acceptance

- support for research data, including large and complex data types

- gold Open Access which fosters wider collaboration and increased citations

- maximum visibility for your research: over 100M website views per year

At BMC, research is always in progress.

Learn more biomedcentral.com/submissions 